\title{
Export of Educational Services as a Component of University Leadership in the Innovation Field
}

\author{
Marina Perederiy \\ Faculty of innovation and production organization \\ Platov South-Russian State Polytechnic University (NPI) \\ Prosveschenia str. 132, 346428 Novocherkassk \\ Russian Federation \\ e-mail: p_m_v@yandex.ru \\ Larissa Borovaya \\ Faculty of innovation and production organization \\ Platov South-Russian State Polytechnic University (NPI) \\ Prosveschenia str. 132, 346428 Novocherkassk \\ Russian Federation \\ e-mail: perl@gmail.com \\ Mikaela Kobazeva \\ Faculty of innovation and production organization \\ Platov South-Russian State Polytechnic University (NPI) \\ Prosveschenia str. 132, 46428 Novocherkassk \\ Russian Federation \\ e-mail: mikaelakobazeva@yandex.ru
}

\begin{abstract}
Our paper examines the features of the impact of the export of educational services of a technical university on its position in the educational institutions' ratings, reflecting the nature of its innovative activities. It has been proved that the conditions, under which innovation activity of the university and export of educational services are being conducted, are closely related and based on a common institutional framework. The approaches to the development of methods of university's innovation activity management in terms of organizing international cooperation and export of educational services have been proposed.
\end{abstract}

\section{Introduction}

Leadership issues in Russian higher education are directly related to the assessment of the level of particular universities, academies and institutes. This is significantly associated with the formation of various ratings, which has become widespread after the collapse of the Soviet Union and the declared course for the integration of Russian higher education into the world educational space. At the same time, not only widely known over the world ratings are applied, such as: QS World University Rankings, THE WUR-2019, and so forth, but also ratings of Russian expert credit rating agency such as: Rating of Russian universities 2017, Top-100 Russian universities by Expert RA 2017.

Besides, in assessing the work of Russian higher education institutions the Ministry of Higher Education and Science of the Russian Federation practically applies rating methods, establishing operating rate set of universities and their limit values.

Usually an assessment is taken according to indicator sets, reflecting key areas of dominance at the university: education, research, citation, income from research and project activities, and international activity.

Thus, international activity (called as "Export of educational services" in modern Russia) and innovation activity are becoming the most important components of university's assessment in its pursuit of leadership.

Any innovation activity is conducted under conditions of rather high risks. Innovation activity in Russian higher education is likewise associated with specific risks, conditioned by characteristics of higher education institutions. Some of them are related to the specifics of Russian legislation, uppermost the Federal law "About higher education in the Russian Federation".

This law sets a goal of innovation activity in educational institutions: to ensure modernization and development of educational system in consideration of guidelines of socioeconomic development of the Russian Federation, implementation of priority of the Russian Federation national educational policy. 
The same section of the act statutorily sets the concept of experimental activity in an education institution as the activity aimed at development, approbation and adoption of new educational technologies and educational resources, which is accomplished experimentally.

Thus, innovation activity and innovation infrastructure of higher education are associated by law exclusively with the development and modernization of educational activity, which seems to be at least illogical from the perspective of the tendencies, declared by the leaders of Russian education, towards integration of Russian universities into world trends of higher professional education development (Vasilieva 2016; Kotyukov 2018), which are linked to research activity of universities. In Western countries precisely universities are the main executors of scientific research and development, they perform the functions, assigned in Russia to the institutions of the Russian Academy of Sciences (Schuchinov and Ladyzhets 2008; Lipatnikova and Moskalenko 1973).

Therefore, scientific and educational activities of universities are considered by modern Russian legislation in different procedural and institutional fields, and innovation activity is associated exclusively with the development of educational technologies. In this case, the basis of the unity of research and educational process, which is the principle that underlies the activities of university, upon which new knowledge is generated by the exploratory practice and is transferred to students during educational activities, is violated (Clark 2007). In the contexts of our study, it can be affirmed that this situation leads to the instability of scientific and innovation activities and increases risks, associated with the working of university's innovation system.

This situation is deteriorated by the fact, that under the circumstances a significant part of university research projects is carried out within the framework of one-time grants from Russian Foundation for Basic Research and Russian Science Foundation and is unstable in many cases.

Similar risks are also characteristic of international activities of Russian universities, which, as has been mentioned above, in many cases reduces to export of educational services, which means education of foreign students on established educational programs of Russian universities. It should be noted that in this case it's generally about students form near abroad countries and developing countries in Asia and Africa.

These risks are associated with the probabilistic nature of foreign enrollee admission, dissatisfaction of some of them with the fact that the established educational programs of Russian universities are not flexible enough and fail to take fully into account students' needs related to their future employment.

Obviously, one of the ways to overcome these problems and, consequently, to increase the level of international activity is to develop personalized forms of work with foreign students and other categories of foreign citizens. First of all, these are internships, postgraduate studies (in terms of research and dissertation work), "project semester", joint research projects with foreign partners, etc. Obviously, the promotion of these forms of work is an innovative task.

Besides, competitiveness of Russian universities in terms of international activities and export of educational services is significantly reduced by the fact that the majority of educational programs are taught in Russian, and the creation of English- and French-speaking student groups encounters teachers' insufficient linguistic qualification. Obviously, this problem should be solved, basing on innovative approaches and tools.

\section{The role of technical universities in Russian regions and the problems of academic leadership}

The collapse of the Soviet Union and the change of power in all the countries that formerly formed the Communist bloc led to large losses in the human capital of the countries eastern European. Studies carried out by different authors (Anderson 2002, Tondl 2003, Steffen 2008) and others show that the reasons for this were the closure of numerous high-tech enterprises that could not withstand competition in the free market, the lack of state support for the national economy, the crisis of General and vocational education, the emigration of many specialists to Europe and North America.

To clarify the role of various universities and other institutions of higher education in providing Russian regions with specialists and maintaining human capital, the authors performed a sociological study in the southern Federal district of Russia in 2017 and 2018. In the process of this study, a survey and questioning of employees of industrial enterprises of different specialization was carried out. The study was conducted at 137 enterprises located in the cities of Rostov region (Rostov-on-don, Novocherkassk, Taganrog), Volgograd region (Volgograd, Kotelnikovo, Volzhsky), Krasnodar region (Krasnodar, Armavir, Novorossiysk) and the Republic of Adygea (Maykop). The study involved 2,138 specialists of different specialties and different levels of management. This allows us to consider the study data representative.

The study was conducted mainly in large enterprises and business groups (with more than 650 employees). The exceptions were regional branches of commercial banks and some trading companies. The largest studied workers belonged to the enterprises of mechanical engineering (among them were included, also, metallurgical enterprises and enterprises producing metal structures) and the chemical industry (among them were included, also, enterprises producing cement and some other building materials). About half of the enterprises studied are located in small and medium-sized cities. 
Most of the specialists involved in the study were trained in universities and other higher educational institutions located in the South of Russia. At the same time, graduates of higher educational institutions located in regional centers (Volgograd, Rostov-on-don, Krasnodar) and graduates of higher educational institutions located in other cities of the region were considered separately. The results of the study are presented in tables 1 and 2.

Table 1. Composition and structure of employees of enterprises of the South of Russia by place of their professional education

\begin{tabular}{|c|c|c|c|c|c|c|}
\hline \multirow{2}{*}{$\begin{array}{l}\text { Sector of the } \\
\text { economy }\end{array}$} & \multirow[b]{2}{*}{$\begin{array}{c}\text { Number } \\
\text { of the } \\
\text { examined } \\
\text { enterpris } \\
\text { es }\end{array}$} & \multicolumn{5}{|c|}{ Percentage of employees who have received vocational education in: } \\
\hline & & $\begin{array}{c}\text { Moscow } \\
\text { and Saint- } \\
\text { Petersburg }\end{array}$ & $\begin{array}{c}\text { cities of the } \\
\text { Southern } \\
\text { Federal } \\
\text { District } \\
\end{array}$ & $\begin{array}{l}\text { towns of the } \\
\text { Southern } \\
\text { Federal } \\
\text { District } \\
\end{array}$ & $\begin{array}{c}\text { other regions } \\
\text { of Russia }\end{array}$ & $\begin{array}{c}\text { foreign } \\
\text { countries }\end{array}$ \\
\hline \multicolumn{7}{|c|}{ Engineering departments } \\
\hline $\begin{array}{l}\text { Mechanical } \\
\text { engineering and } \\
\text { metallurgy }\end{array}$ & 10 & 1,3 & 32,4 & 38,3 & 22,3 & 5,7 \\
\hline $\begin{array}{l}\text { Chemical industry } \\
\text { and production of } \\
\text { building materials }\end{array}$ & 8 & 2,1 & 19,4 & 36,9 & 24,4 & 17,2 \\
\hline Food industry & 11 & 0,3 & 18,4 & 38,1 & 12,3 & 7,1 \\
\hline Agriculture & 14 & 0,6 & 12,3 & 58,4 & 15,6 & 13,1 \\
\hline Building & 8 & 0,7 & 21,2 & 53,1 & 14,3 & 10,7 \\
\hline Transportation & 8 & 0,5 & 21,4 & 56,7 & 12,1 & 9,3 \\
\hline Trading & 10 & 0,6 & 24,2 & 49,3 & 13,6 & 12,3 \\
\hline Banks and insurance & 12 & 1,3 & 37,4 & 32,2 & 21,2 & 7,9 \\
\hline \multicolumn{7}{|c|}{ Economic departments } \\
\hline $\begin{array}{c}\text { Mechanical } \\
\text { engineering and } \\
\text { metallurgy }\end{array}$ & 10 & 0,9 & 25,4 & 31,3 & 18,4 & \\
\hline $\begin{array}{l}\text { Chemical industry } \\
\text { and production of } \\
\text { building materials }\end{array}$ & 8 & 1,1 & 26,4 & 30,5 & 19,2 & 22,8 \\
\hline Food industry & 11 & 0,6 & 21,3 & 32,0 & 16,3 & 29,8 \\
\hline Agriculture & 14 & 0,1 & 18,4 & 40,1 & 13,4 & 28 \\
\hline Building & 8 & 0,4 & 19,3 & 41,2 & 22,3 & 16,8 \\
\hline Transportation & 8 & 0,5 & 18,7 & 43,1 & 26,1 & 11,6 \\
\hline Trading & 10 & 0,6 & 20,1 & 47,4 & 20,1 & 11,8 \\
\hline Banks and insurance & 12 & 0,9 & 19,8 & 30,6 & 19,1 & $29,60,2$ \\
\hline \multicolumn{7}{|c|}{ Managers } \\
\hline $\begin{array}{c}\text { Mechanical } \\
\text { engineering and } \\
\text { metallurgy }\end{array}$ & 10 & 0,2 & 20,3 & 51,7 & 17,3 & 10,5 \\
\hline $\begin{array}{l}\text { Chemical industry } \\
\text { and production of } \\
\text { building materials }\end{array}$ & 8 & 0,3 & 21,1 & 45,7 & 21,1 & 11,8 \\
\hline Food industry & 11 & 0,2 & 20,1 & 46,9 & 20,1 & 12,7 \\
\hline Agriculture & 14 & 0,1 & 19,3 & 65,9 & 10,3 & 4,4 \\
\hline Building & 8 & 0,2 & 20,3 & 51,8 & 17,9 & 9,8 \\
\hline Transportation & 8 & 0,3 & 19,2 & 49,3 & 20,3 & 10,9 \\
\hline Trading & 10 & 0,1 & 38,2 & 51,6 & 17,3 & 10,4 \\
\hline Banks and insurance & 12 & 0,2 & 39,3 & 32,7 & 19,3 & 8,5 \\
\hline
\end{tabular}

Source: Kolbachev and Borovaya (2019)

Table 1 shows the location of higher education institutions where specialists were educated in accordance with their profession. At the same time, it was found that a significant part of the studied specialists do not work in full accordance with their professional education. This situation is illustrated in Table 2.

Tables 1 and 2 show that the main part of the specialists working at the enterprises of the South of Russia received higher professional education in the same region. It is very small among specialists graduates of the universities of Moscow and St. Petersburg, who are extremely reluctant to go to work in the regions of Russia preferring to work in the capitals, in Europe and North America. 
Table 2. Compliance of work with the received education

\begin{tabular}{|l|c|c|c|c|}
\hline \multicolumn{1}{|c|}{ Sector of the economy } & \multicolumn{3}{|c|}{ Percent of the employees, and how their chief subject answers the } \\
purpose of the professional activity
\end{tabular}

Source: Kolbachev and Borovaya (2019)

Many specialists do not work in full accordance with their education (table. 2). The reason for this (among other reasons) is the inability to get a job according to the education received in their region. At the same time, residents of regions are reluctant to change their place of residence (Heleniak 2012). However, many of these specialists received additional postgraduate education in accordance with their work.

The above given data implies that Russian universities (primarily technical ones) have an important place in solving the problem of human capital strengthening in the country. It is obvious that the desire of universities for academic leadership should contribute to solving this problem.

\section{Cognitive methods and their role in the pursuit of academic leadership}

In meeting the challenges of innovation development of international activities of universities and export of educational services human factor effort, which plays a crucial part in learning and research process improvement for the benefit of foreign and postgraduate students, is essential. This necessitates the application of cognitive methods in learning and scientific process management with subsequent establishment of Artificial Cognitive Systems. This provides further condition for university's leadership in terms of innovation and international activities.

Moreover, formal approaches to generating new technical solutions, such as Kornai's system paradigm, described in his publication (Kornai 2002), are very important.

This Kornai's publication enables to trace methodological basis of the systematic representation of the production system, as well as to adopt approaches to classification and analysis of both available and possible options of production systems. The essence of the system paradigm is that the functioning of economy and society, such as production process performance, distribution, exchange and consumption of material and intangible values, is viewed through the prism of creation, interaction and transformation of socio-economic systems. Kornai's ideas for application of system paradigm were developed mainly in the Russian researcher's publications. On its basis methods of managing formation and development of production (in fact, socio-technical) systems in the various manufacturing sectors were worked out. This experience enables to hypothesize the possibility of application of system paradigm for managing the creation of technical systems and objects, creation of new technologies and solution to other engineering problems under the conditions of NBIC-convergence.

Methods of behaviorism (Staddon 2014; Mace and Critchfield 2010) can be included to such methods , as well as other applied approaches, among which the theory of inventive problem solving (TRIZ) is major. The author of this theory is Altshuller (1984), and the theory was developed in the writings of his students (Zlotin and Zusman 2006; Zlotin and Zusman 2011). In the context of our study, the method of generating engineering solutions, developed by Polovinkin (1988) at the end of the last century, named «blagodatnye systems» and improved by his students (Zaboleeva-Zotova et al. 2013; Ukustov et al. 2013), is of interest.

These methods may include a functionally-oriented approach to the technological process creation, developed about 10 years ago in Donbass (Mikhailov et al. 2012). They are based on compositions of the main particularities and principle of the syntheses multifunction (hybrid); macro-, micro- and nanotechnology. These technologies pertain to new class organizing-technological forms technology.

Methods of value analysis (VA) and value engineering (VE) are inherently cognitive. In addition, VA and $\mathrm{VE}$ are examples of positive impact of economic (value) methods on technical solutions formation (Miles 1989). 
It is noteworthy that the above-mentioned methods were elaborated in Soviet Union, and some of them are being improved in modern Russia. The possibility to teach these methods to foreign students of engineering majors is a strong point of Russian higher education.

\section{Harmonization of international and innovation activities of university}

The above-described approaches and methods of innovation activity management are used at SRSPU (NPI) in the teaching foreign students.

At the university discipline programs for "Economics and industrial management" for undergraduate students and "Fundamentals of engineering economics" for graduate students, in which above-mentioned methods are studied, have been developed. Besides, a special program for summer English school of organizational and economic methods of engineering activities has been developed.

Concurrently, a number of projects, in which harmonized international and innovation activities are combined with interaction with foreign universities conducting research on related topics, is implemented at the university.

An example of networking with foreign partners based on the proximity to the subject matter of research is cooperation of the South-Russian State Polytechnic University (NPI) and Federal University of Toulouse MidiPyrénées. In this case, an interaction between the Department of Industrial and Innovation Management of the Faculty of Innovation Studies and Industrial Management and the SDC LGP laboratory in Tarbes was organized. In this case, the proximity to the research subject matter of the SRSPU (NPI) on the problems of industrial system management, creation of human-oriented manufactures, and technical systems (Kolbachev and Salnikova 2019) and research of SDC LGP in the field of PLM-systems, Bayesian networks, and so forth (Liu et al. 2016; Pérès et al. 2016; Bouzarour-Amokrane et al. 2015) has become the basis for the development of joint research and academic exchange plans.

\section{Conclusions}

Leadership issues in Russian higher education are directly related to the assessment of the level of individual universities, academies and institutes, as well as their individual units and individual projects. To a large extent this is due to the formation of various ratings, which have become widespread after the collapse of the Soviet Union, and focus declared by Russian higher education management on the integration of Russian higher professional education into the world educational space.

University's position in the ratings is significantly affected by the level of international and innovation activities. The conditions, in which the university performs innovation activity and export of educational services, are closely related and based on a common institutional basis. The same risks of conjunctural and systemic nature are inherent in innovation and international activity.

The quality of international and innovation activity of university strongly depends on the use of cognitivebased methods of innovation and development management. The basic of these is Kornai's system paradigm and methods derived from it.

Analysis of the role of technical universities located in the Russian province showed that they play a decisive role in maintaining and increasing the level of human capital of Russian people. This factor is poorly reflected in the current university rating systems. These circumstances require correction. There is some experience with this at Platov South-Russian State Polytechnic University (NPI).

\section{References}

Altshuller GS, Creativity as an Exact Science, $1^{\text {st }}$ edn. (Gordon and Breach Science Publishers: Amsterdam, The Netherlands, 1984), $320 \mathrm{p}$.

Anderson BA (2002) Russia faces depopulation? Dynamics of population decline. Population and Environment 23(5):437-464.

Bouzarour-Amokrane Y, Tchangani A, Pérès F (2015) Decision evaluation process in end-of-life systems management. Journal of Manufacturing Systems 37(3):715-728. doi: 10.1016/j.jmsy.2015.03.007

Clark W, Academic Charisma and the Origins of the Research University, $1^{\text {st }}$ edn. (University of Chicago Press: Chicago, USA, 2007), 662 p. 
Heleniak T (2012) International Comparisons of Population Mobility in Russia. International Journal of Population Research 2012: 13. doi: 10.1155/2012/361497.

human capital upbuilding. Materials of the International Conference New Perspectives in Science Education 9: 5. Kolbachev E, Borovaya L, Salnikova Y (2019) Regional strategies for the development of higher education and Kolbachev E, Salnikova Y (2019) Actuarial Models in the Design of Human-oriented Production Systems and Products. Advances in Intelligent Systems and Computing 1018:163-169. doi:10.1007/978-3-030-25629-6_26.

Kornai J (2002) System paradigm. Voprosy ekonomiki 4:3-34.

Kotyukov M (2018) We spend 1\% of GDP on research, this amount is necessary to increase. https://www.ntv.ru/video/1673800/ . Accessed 4 November 2019

Lipatnikova GI, Moskalenko AE. Dokumenty po istorii evropeyskikh universitetov XII-XV vekov, $1^{\text {st }}$ edn. (Ministry of Education of Russian SFSR: Voronezh, USSR, 1973), 157 p.

Liu Q, Tchangani A, Pérès F (2016) Modelling complex large scale systems using object oriented Bayesian networks (OOBN). IFAC-PapersOnLine 49 (12):127-132. doi: 10.1016/j.ifacol.2016.07.562.

Mace FC, Critchfield TS (2010) Translational research in behavior analysis: historic traditions and imperative for the future. Journal of the experimental analysis of behavior 93 (3): 293-312. doi: 10.1901/jeab.2010.93-293.

Mikhailov A, Sydorova E, Selivra S (2012) Functional-oriented approach for analysis of physical-mechanical processes in the cutting zone. International Journal of Modern Manufacturing Technologies 4 (1): 85-90.

Miles LD, Techniques of Value Analysis and Engineering, $3^{\text {rd }}$ edn. (McGraw-Hill: New York, USA, 1989), 366 p.

Pérès F, Liu Q, Tchangani A (2016) Object oriented Bayesian Network for complex system risk assessment. IFACPapersOnLine 49(28):31-36. doi: 10.1016/j.ifacol.2016.11.006.

Polovinkin AI, Osnovy inzhenernogo tvorchestva, $2^{\text {st }}$ edn. (Mechanical Engineering: Moscow, USSR, 1988), 368 p.

QS World University Rankings (2019) https://www.topuniversities.com/qs-world-university-rankings . Accessed 4 November 2019

Rating of Russian universities (2017) http://www.edu.ru/abitur/act.9/index.php?rating/rating-2017.html . Accessed 4 November 2019

Schuchinov OS, Ladyzhets NS (2008) Sovremennye konceptualnye podhody v povyshenii effektivnosti upravleniya naukoy v zapadnykh universitetakh. Vestnik Udmurtskogo universiteta 1:3-12.

Staddon J, The New Behaviorism, 2 ${ }^{\text {nd }}$ edn. (Psychology Press: Philadelphia, USA, 2014), 294 p.

Steffen W, Stephan J (2008) The Role of Human Capital and Managerial Skills in Explaining Productivity Gaps Between East and West. Eastern European Economics 46 (6): 5-24. doi: 10.2753/eee0012-8775460601

Tondl G, Vuksic G (2003) What makes regions in Eastern Europe catching up? The role of foreign investment, human resources and geography. IEF Working Papers 51:3-41

Top-100 Russian universities by Expert RA (2017) https://expert.ru/ratings/top-100-rossijskih-vuzov-ot-raekspert/ Accessed 4 November 2019

Ukustov S, Fomenkov S, Polovinkin A (2013) Wrong metrics of success for open source software. Materials of the Proceedings of the IADIS International Conference Web Based Communities and Social Media and Collaborative Technologies 2013: 97-99.

Vasilieva O (2016) Rossiyskaya shkola dolzhna davat horoshee bazovoye obrazovaniye https://alexandrpalkin.livejournal.com/5502606.html Accessed on 4 Nov 2019

World University Rankings 2019 https:/www.timeshighereducation.com/world-university-rankings/2019/worldranking\#!/page/0/length/25/sort_by/rank/sort_order/asc/cols/stats Accessed 4 Nov 2019

Zaboleeva-Zotova AV, Bobkov AS, Orlova YA, Rozaliev VL, Polovinkin AI (2013) Automated identification of human emotions based on analysis of body movements. Materials of the Proceedings of the IADIS International Conferences Interfaces and Human Computer Interaction and Game and Entertainment Technologies, pp. $299-304$

Zlotin B, Zusman A (2006) Patterns of evolution: recent findings on structure and origin. Materials of the Altshuller's TRIZ Institute Conference TRIZCON 2006. Ideation International, Milwaukee, pp. 1-49 
Zlotin B, Zusman A, Hallfell F (2011) TRIZ to invent your future utilizing directed evolution methodology. Procedia Engineering 9 :126-134. doi: 10.1016/j.proeng.2011.03.106 